\title{
Pendidikan Islam dalam Perspektif Antropologi
}

\author{
Herman Wicaksono \\ Pascasarjana IAIN Purwokerto \\ hermansukses1212@gmail.com \\ DOI: $10.18326 /$ mudarrisa.v8i2.201-228
}

\begin{abstract}
Abstrak
Tulisan ini bertujuan untuk menjelaskan tentang pendidikan Islam dalam perspektif antropologi. Adapun jenis penelitian yang digunakan dalam penelitian ini adalah penelitian kepustakaan (library research) dengan metode kualitatif. Penelitian ini sangat perlu diteliti mengingat ilmu antropologi merupakan ilmu tentang manusia terkhusus lagi antropologi budaya yang memandang bahwa manusia merupakan makhluk yang berbudaya. Penelitian ini didapatkan hasil bahwa Islam dan antropologi memiliki pandangan yang sama terkait dengan pendidikan Islam. Kesamaan tersebut diantaranya terlihat pada kesamaan pandangan tentang konsep manusia. Manusia sebagai makhluk yang memiliki potensi atau fitrah sama-sama diakui oleh antropologi dan Islam. Begitu pula dalam aktifitas pendidikan, antara Islam dan antropologi pun memiliki beberapa kesamaan yang subtantif. Pendidikan hendaknya bisa disesuaikan dengan kebudayaan yang ada di sekitar. Hal ini karena selain antropologi menghendaki yang demikian, ternyata Islam juga sangat mengapresiasi mereka yang menghargai budayanya, tentunya budayabudaya yang tidak bertentangan dengan prinsip-prinsip ajaran Islam. Pada akhirnya, pandangan antropologi terhadap pendidikan Islam mengarahkan agar setiap aktivitas pendidikan tidak lepas dari aspek budaya yang berlaku baik dari segi pendidik, peserta didik, tujuan pendidikan, metode pendidikan, serta konteks/lingkungan pendidikan.
\end{abstract}

This article aims to explain Islamic education in the perspective of anthropology. The type of research used in this research is library 
research with qualitative methods. This research is very necessary to study because anthropology is the study of man especially cultural anthropology which holds that humans are creatures of culture. This study showed that Islam and anthropology have similar views related to Islamic education. The similarity can be seen from a common view of the human concept. Human beings have the potential or disposition equally recognized by anthropology and Islam. In educational activities, between Islam and anthropology also has some similarities substantive. Education should be adapted to the culture around. This is because in addition to anthropology such desires, it turns out Islam also greatly appreciate those who appreciate culture, of course, cultures that do not contradict the principles of Islam. Finally, the view of anthropology to Islamic education shows that every educational activity cannot be separated from the cultural aspect that applies both in terms of educators, learners, educational objectives, methods of education, as well as the context/environment education.

Kata kunci: pendidikan Islam, antropologi, kebudayaan

\section{Pendahuluan}

Pendidikan merupakan salah satu aspek penentu keberhasilan hidup seseorang. Sebab pendidikan, khususnya Pendidikan Islam mampu membentuk sikap dan karakter yang unggul, sehingga melahirkan generasi yang unggul pula (Latifah, Hernawati, 2009:1). Oleh karenanya, sebuah aktivitas yang disebut dengan pendidikan hendaknya mampu memenuhi kebutuhan setiap individu yang terjun di dalamnya. Kebutuhan yang heterogen masing-masing individu hendaknya menjadi acuan utama para penyelenggara pendidikan dalam menyelenggarakan pendidikan. Hal ini karena kebutuhan sangat erat kaitannya dengan kebudayaan. Kebudayaan yang berbeda akan mempengaruhi kebutuhan serta pandangan hidup seseorang. 
Dengan semakin berkembangnya berbagai hal di era modern ini seperti teknologi, informasi, dan komunikasi, pendidikan terlihat seolah mulai menjauh dari kebudayaan asli masyarakat Indonesia. Terlebih lagi, pendidikan di masyarakat perkotaan seolah sudah sangat jauh dari nilainilai budaya ketimuran. Padahal, kalau dicermati secara lebih mendalam, hal yang demikian itu lah yang akan menyebabkan merosotnya moral bangsa serta munculnya degradasi moral khususnya di kalangan pemuda dan pemudi. Dengan kata lain, pendidikan termasuk pendidikan Islam hendaknya senantiasa memperhatikan budaya setempat selagi budaya tersebut tidak bertentangan dengan ajaran Islam, dan selaras dengan citacita pendidikan nasional yaitu menciptakan kehidupan bangsa yang cerdas dan berkemajuan (Entin, 2015:48).

Selain ditentukan oleh modernisitas dalam berbagai aspek kehidupan, berkembangnya sebuah aktivitas pendidikan dalam suatu wilayah tertentu sangat dipengaruhi oleh konstruk masyarakat yang ada, baik dari segi kebudayaannya maupun dari segi yang lainnya termasuk dari segi agama yang dalam hal ini (pendidikan Islam) tentunya agama Islam. Antropologi, sebagaimana pendapat Clifford Geertz, akan memberikan interpretasi-interpretasi mengenai aktivitas keagamaan suatu agama tertentu. Tentunya, jika yang menjadi pembahasan di sini adalah pendidikan Islam, maka yang diharapkan adalah jawaban dari pertanyaan bagaimana Islam dilihat dari kacamata antropologi serta kontribusinya dalam pendidikan di era modern ini.

Sebagai sebuah tawaran, pendidikan termasuk pendidikan Islam dalam implementasinya hendaknya bisa menyesuaikan dengan kondisi 
sosial budaya masyarakat yang ada. Suatu pendidikan yang tidak mau memperhatikan khasanah kebudayaan setempat, lambat laun pasti akan memberikan efek buruk bagi pendidikan Islam sekaligus bagi kebudayaan yang ada. Demikian juga, peran kebudayaan bagi aktifitas pendidikan sangatlah urgen. Maka dari itu, dengan melihat latar belakang yang ada, ditambah dengan masih minimnya pembahasan terkait tema ini, dianggap perlu untuk dibahas sebuah tema pendidikan Islam dalam perspektif antropologi. Lebih lanjut, dengan adanya pandangan antropologi terhadap pendidikan Islam, diharapkanmampu membuka khasanah pemahaman baru bahwa pendidikan merupakan wujud kesatuan dari berbagai cabang ilmu pengetahuan.

\section{Metode Penelitian}

Jenis penelitian yang akan digunakan dalam penelitian ini adalah library research (penelitian kepustakaan). Riset kepustakaan ini adalah dilakukan mencari data atau informasi riset melalui membaca jurnal ilmiah, buku-buku, referensi dan bahan-bahan publikasi yang tersedia di perpustakaan (Ruslan, 2004:31). Oleh karenanya, objek penelitiannya adalah berupa buku-buku, kitab-kitab, majalah, jurnal serta tulisan lain yang dapat memberikan informasi sesuai dengan kebutuhan penulis. Adapun jenis penelitian yang akan penulis lakukan, maka metode pengumpulan data yang digunakan adalah metode dokumentasi yaitu mengumpulkan data dengan melihat atau mencatat suatu laporan yang sudah tersedia (Tanzeh, 2011:92). Setelah data terkumpul selanjutnya dipilih dan dipilah serta diklasifikasikan untuk kemudian dilakukan 
analisis data. Sedangkan secara umum analisis data yang dilakukan oleh penulis menggunakan kajian isi (content analysis). Menurut Lincoln (1981:240), sebagaimana dikutip oleh Moloeng memberikan definisi bahwa kajian isi merupakan teknik yang digunakan untuk menarik kesimpulan melalui usaha menemukan karakteristik pesan dan dilakukan secara obyektif dan sistematis (Moloeng, 2014:220). Metode analisis yang digunakan adalah metode analisis deskriptif kualitatif. Dengan analisis deskriptif kualitatif dianggap dapat memaparkan hasil penelitian secara sistematis, komprehensif dan mendalam,

\section{Pendidikan Islam dan Antropologi}

\section{Pendidikan Islam}

Bicara pendidikan, tentu tidak luput dari pembicaraan tentang manusia. Manusia sebagai pelaku dalam pendidikan memegang peranan yang urgen dalam menentukan arah sebuah sistem maupun model pendidikan, termasuk pendidikan Islam. Para ahli pendidikan muslim umumnya sependapat bahwa teori dan praktik kependidikan Islam harus didasarkan pada konsepsi dasar tentang manusia. Pembicaraan seputar persoalan ini merupakan sesuatu yang sangat vital dalam pendidikan (Umar, 2010:18). Ali Ashraf, sebagaimana dikutip oleh Bukhari Umar (2010:19) menjelaskan bahwa pendidikan tidak akan dapat dipahami secara jelas tanpa terlebih dahulu memahami penafsiran Islam tentang pengembangan individu seutuhnya.

Pendidikan Islam secara bahasa terdiri atas dua kata, yakni pendidikan dan Islam. Pendidikan secara bahasa dimaknai sebagai hal 
(perbuatan, cara, dan sebagainya) mendidik (Tim Penyusun Kamus Pusat Bahasa, 2008:353). Sedangkan Islam secara bahasa dimaknai sebagai agama yang diajarkan oleh Nabi Muhammad SAW (Tim Penyusun Kamus Pusat Bahasa, 2008:601). Sehingga, jika dimaknai secara bahasa maka pendidikan Islam berarti hal (perbuatan, cara, dan sebagainya) mendidik yang berdasarkan pada ajaran Nabi Muhammad SAW. Adapun secara istilah, pendidikan Islam memiliki definisi yang sangat beragam.

Pendidikan dapat dirumuskan sebagai upaya terprogram mengantisipasi perubahan sosial oleh pendidik dan membantu subyek didik dan satuan sosial berkembang ke tingkat yang lebih baik dengan cara/jalan yang juga baik (Muhadjir, 2003:7). Di sini, Muhadjir menekankan pada aspek perubahan sosial. Artinya, suatu aktivitas pendidikan hendaknya mampu digunakan sebagai bekal untuk menghadapi perubahan sosial yang tentunya akan selalu terjadi dari waktu ke waktu. Menurut Muhadjir, sebuah aktivitas mempunyai 5 (lima) unsur pokok, yakni yang memberi (pendidik), yang menerima (peserta didik), tujuan, dan cara (metode), serta konteks yang positif (Muhadjir, 2003:1-4).

Mustafa sebagaimana dikutip oleh Fatah Syukur (2012:2) mendefinisikan pendidikan Islam sebagai suatu proses bimbingan dari pendidik terhadap perkembangan jasmani, rohani, dan akal peserta didik ke arah terbentuknya pribadi muslim yang baik. Sementara itu Zakiyah Drajat mendefinisikan pendidikan Islam sebagai pendidikan yang lebih bayak ditunjukkan kepada perbaikan sikap mental yang akan terwujud dalam amal perbuatan, baik bagi keperluan diri sendiri maupun orang 
lain yang bersifat teoritis dan praktis (Syukur, 2012:3). Dari kedua definisi tersebut dapat terlihat bahwa yang jadi penekanan dari pendidikan Islam adalah menjadi manusia yang baik yang mana kebaikan itu tidak hanya untuk diri sendiri, namun juga bagi orang lain.

Rahman memahami pendidikan Islam sebagai proses untuk menghasilkan manusia (ilmuwan) integratif, yang padanya terkumpul sifat-sifat seperti kritis, kreatif, dinamis, inovatif, progresif, jujur, dan sebagainya (Sutrisno, 2006:170). Dalam hal ini Rahman menekankan aspek integratif, artinya output dari pendidikan Islam seyogyanya tidak hanya melahirkan individu yang mahir dalam ilmu-ilmu agama saja, namun juga cerdas dalam ilmu-ilmu lain seperti ilmu-ilmu sosial dan sains. Sehingga sangat ironis apabila sebuah sistem pendidikan Islam hanya memfokuskan pendidikannya pada satu bidang kajian saja (agama) tanpa adanya integrasi dengan ilmu-ilmu lain.

Berkenaan dengan pengertian pendidikan Islam, secara lebih teknis Endang Saifuddin Anshari sebagaimana dikutip oleh Azyumardi Azra (2012:6) memberikan pengertian pendidikan Islam sebagai "proses bimbingan (pimpinan, tuntutan, dan usulan) oleh subyek didik terhadap perkembangan jiwa (pikiran, perasaan, kemauan, dan intuisi), dan raga obyek didik dengan bahan materi tertentu, pada jangka waktu tertentu, dengan metode tertentu dan dengan alat perlengkapan yang ada ke arah terciptanya pribadi tertentu disertai evaluasi sesuai ajaran Islam. Sementara itu, Roqib (2009:21) menyimpulkan bahwa pendidikan Islam pada hakikatnya menekankan pada tiga hal, yaitu: 1) suatu upaya pendidikan menggunakan metode-metode tertentu khususnya metode 
latihan untuk mencapai kedisiplinan mental peserta didik; 2) bahan pendidikan yang diberikan kepada anak didik berupa bahan materiil, yakni berbagai jenis ilmu pengetahuan dan spiritual, yakni sikap hidup dan pandangan hidup yang dilandasi nilai etis Islam; 3) tujuan pendidikan yang ingin dicapai adalah mengembangkan manusia yang rasional dan berbudi luhur, serta mencapai kesejahteraan masyarakat yang adil dan makmur dalam rengkuhan ridla Allah SWT.

Dari pengertian-pengertian di atas, maka pendidikan Islam sangat menekankan tidak hanya pada aspek jiwa tetapi juga pada aspek raga, artinya sebuah proses pendidikan Islam harus dijalankan secara komprehensif dan menyeluruh.

\section{Antropologi}

\section{Sejarah Antropologi}

Antropologi bermula pada abad XIX sebagai penelitian terhadap asalusul manusia. Penelitian antropologi ini mencakup pencarian fosil yang masih ada, dengan mengkaji keluarga binatang yang paling dekat dengan manusia (primate) serta meneliti masyarakat manusia apakah yang paling tua dan tetap bertahan (survive), masyarakat tersebut disebut masyarakat primitif (Geller, 2012:15).

Berkaitan dengan fase-fase perkembangan ilmu antropologi secara lebih rinci, Koentjaraningrat (1990:1-6) membagi perkembangan tersebut ke dalam empat fase sebagaimana ditunjukkan pada Tabel 1. 
Tabel 1

Sejarah Antropologi

\begin{tabular}{cll}
\hline $\begin{array}{c}\text { Fase pertama } \\
\text { (sebelum 1800) }\end{array}$ & \multicolumn{3}{c}{ Fase kedua } \\
(sekira pertengahan abah ke-19)
\end{tabular}

\section{Definisi Antropologi}

Dalam Kamus Bahasa Indonesia, antropologi berarti ilmu tentang manusia, khususnya tentang asal-usul, perkembangan, adat-istiadat, dan kepercayaannya pada masa lampau (Tim Penyusun Kamus Pusat Bahasa, 2008:78). Antropologi berasal dari bahasa Inggris "anthropology", 
berarti "ilmu tentang manusia". Pada awalnya istilah ini dipergunakan dalam arti yang lain, yaitu "ilmu tentang ciri-ciri tubuh manusia" atau disebut sebagai "ilmu anatomi”) (Koentjaraningrat, 1990:1-6). Jika melihat pada definisi menurut Koentjaraningrat di atas, maka obyek antropologi adalah manusia atau bahkan pernah juga tubuh manusia. sedangkan Clifford Geertz menegaskan bahwa obyek antropologi adalah kebudayaan. Dengan demikian, maka bisa jadi antropologi menurut Geertz adalah ilmu tentang kebudayaan atau budaya. Antropologi menurut Geertz harus menjelaskan secara detail makna dari gerakan atau suatu simbol yang biasa berbeda dari penampilannya (Agus, 2006:142).

\section{Pembagian Antropologi}

Antropologi secara garis besar dipecah menjadi dua bagian, yaitu antropologi fisik/biologi dan antropologi budaya (Shomad, 2004:104). Antropologi fisik dalam arti khusus adalah bagian dari ilmu antropologi yang mencoba mencapai suatu pengertian tentang sejarah terjadinya aneka warna makhluk manusia dipandang dari sudut ciri-ciri tubuhnya, yang memakai sebagai bahan penelitiannya ciri-ciri tubuh, baik yang lahir (fenotipik) seperti warna kulit, warna dan bentuk rambut, indeks tengkorak, bentuk muka, warna mata, bentuk hidung, tinggi dan bentuk tubuh, maupun yang dalam (genotipik), seperti golongan darah dan sebagainya (Koentjaraningrat, 1990:13). Dengan demikian, antropologi fisik lebih menekankan pada aspek fisik pada diri manusia, dan bukan membahas manusia dalam kapasitasnya sebagai makhluk sosial dan makhluk yang berbudaya. 
Jenis yang kedua dari antropologi secara garis besar yakni antropologi budaya. Antropologi budaya adalah cabang besar dari antropologi umum yang menyelidiki kebudayaan pada umumnya dan kebudayaan-kebudayaan dari berbagai bangsa di seluruh dunia. Ilmu ini menyelidiki bagaimana manusia itu mampu berkebudayaan dan mengembangkan kebudayaannya sepanjang zaman (Harsojo, 1982:18). Antropologi budaya terpecah-pecah lagi menjadi banyak sehingga menjadi spesialisasi-spesialisasi, termasuk antropologi pendidikan. Seperti halnya kajian antropologi pada umumnya, antropologi pendidikan berusaha menyusun generalisasi yang bermanfaat tentang manusia dan perilakunya dalam rangka memperoleh pengertian yang lengkap tentang keanekaragaman manusia, khususnya dalam dunia pendidikan. Studi antropologi pendidikan adalah spesialisasi yang termuda dalam antropologi. Setelah dasawarsa tahun 60-an di Amerika Serikat semakin banyak diperlukan keahlian dalam antropologi untuk meneliti masalahmasalah pendidikan, maka antropologi pendidikan kemudian dianggap dapat berdiri sendiri sebagai cabang spesialisasi antropologi yang resmi (Shomad, 2004:104).

Jika melihat pada pemaparan Shomad di atas, maka tampak bahwa yang disorot oleh antropologi terhadap dunia pendidikan adalah manusia. Hal ini tidak berbeda dengan pendidikan Islam yang dalam beberapa buku senantiasa mengawali pembahasan tentang manusia. Sehingga dengan demikian, dalam pembahasan ini yang menjadi pembahasan pertama dan utama adalah pembahasan tentang manusia. 


\section{Konsep Manusia dalam Pendidikan Islam dan Antropologi}

Jika melihat pada penjelasan tentang pendidikan Islam di atas serta melihat pada definisi awal dari antropologi, tampak bahwa ternyata terdapat titik temu antara keduanya yakni tentang manusia. Manusia dalam konsep pendidikan Islam menempati pembahasan paling awal, begitu pula dalam beberapa buku antropologi diantaranya buku yang ditulis oleh Koentjaraningrat, setelah ia membahas azas-azas dan ruang lingkup ilmu antropologi, ia lalu mambahas tentang manusia.

Manusia manurut al-Syaibani sebagaimana dikutip oleh Ahmad Tafsir (2014:26), terdiri atas tiga unsur yang sama pentingnya, yaitu jasmani, akal, dan ruhani. Jasmani, akal, dan ruhani membangun manusia laksana sisi-sisi sebuah segitiga sama kaki. Ketiga unsur tersebut jika dikaitkan dengan pendidikan, tentunya tidak dapat dipisahkan. Hal ini karena setiap manusia dalam segala jenis aktifitasnya termasuk aktifitas pendidikan tidak bisa lepas dari ketiga unsur di atas.

Dalam pendidikan Islam, konsep tentang manusia sering diistilahkan dengan al-insān, al-nās, al-basyār , serta bani adam yang masing-masing memiliki makna yang berbeda-beda satu sama lain. Kesemuanya merupakan istilah-istilah yang diambil dari al-Qur'an.

Al-Insān berasal dari kata uns yang berarti jinak, harmonis. Kata insan tampak sebagai lawan dari makna "binatang liar". Kata insan digunakan al-Qur'an untuk menunjuk kepada manusia dengan segala totalitasnya, jiwa, dan raga (Makbuloh, 2011:42). Selain kata al-insan, al-Quran juga menyebut istilah al-nas yang memiliki makna berkaitan dengan interaksi kehidupan manusia yang bersifat kolektif, seperti 
kepemimpinan, perubahan sosial, dan perubahan alam (Makbuloh, 2011:44); al-basyar yang menunjukkan pada gambaran manusia secara materi yang dapat dilihat seperti makan, minum, berjalan, dan berusaha untuk memenuhi kebutuhannya. sedangkan bani adam yang menunjukkan manusia dari sudut keturunannya, yaitu manusia keturunan dari Nabi Adam a.s.

Dalam kaitannya dengan pendidikan Islam, manusia memegang peranan yang sangat urgen. Abd. Rahman Assegaf sebagaimana dikutip oleh Zainur Rofiq (2014:39) menjelaskan bahwa manusia adalah makhluk yang dapat dididik dan mendidik, sedangkan makhluk lain tidak. Dalam potensi ini manusia dapat menjadi subjek dan objek pengembangan diri. Pendidikan pun harus berpijak pada potensi manusia, karena potensi manusia tidak akan bisa berkembang tanpa adanya rangsangan dari luar berupa pendidikan.

Adapun dalam pandangan antropologi, manusia merupakan makhluk sosial (hayawān ijtimā' $\bar{l}$ ), yang berkelompok dan bermasyarakat serta saling bergantung satu sama lainnya, untuk bertahan hidup dan dan memenuhi kebutuhan hidupnya. Hal yang membedakan manusia dengan makhluk lainnya adalah bahwa manusia merupakan makhluk budaya (hayawān tsaqāfî). Manusia menciptakan dan memindahkan pengetahuan, serta bersama-sama mempertahankan tradisi berpikir dan berperilaku. Mereka menciptakan hal-hal yang tidak bisa diciptakan oleh makhluk lain, misalnya peralatan yang rumit, merumuskan sistem moneter, menunjuk atau memilih pemimpin politik, mengawinkan satu dengan yang lain, melakukan ritual keagamaan, meminjamkan benda 
miliknya, menagih utang, atau melekatkan nilai-nilai simbolis tertentu pada berbagai aktivitasnya (Mahmud, 2012:23).

Oleh karenanya tidaklah mengherankan apabila Allah SWT telah menetapkan manusia sebagai khalifah di muka bumi ini.

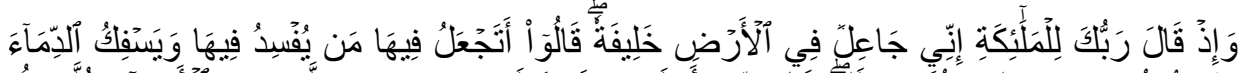

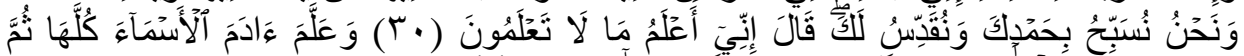

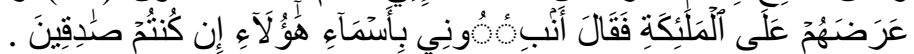
Ingatlah ketika Tuhanmu berfirman kepada para Malaikat: "Sesungguhnya Aku hendak menjadikan seorang khalifah di muka bumi". Mereka berkata: "Mengapa Engkau hendak menjadikan (khalifah) di bumi itu orang yang akan membuat kerusakan padanya dan menumpahkan darah, padahal kami senantiasa bertasbih dengan memuji Engkau dan mensucikan Engkau?" Tuhan berfirman: "Sesungguhnya Aku mengetahui apa yang tidak kamu ketahui"

Dan Dia mengajarkan kepada Adam nama-nama (benda-benda) seluruhnya, kemudian mengemukakannya kepada para Malaikat lalu berfirman: "Sebutkanlah kepada-Ku nama benda-benda itu jika kamu mamang benar orang-orang yang benar! (Q.S. al-Baqarah: 30-31)

Ayat ini secara tidak langsung mengindikasikan bahwa manusia merupakan makhluk yang memiliki kemampuan untuk mengembangkan potensi yang ada dalam dirinya yang artinya juga mengindikasikan bahwa manusia merupakan makhluk yang berbudaya. Hal tersebut ditunjukkan dengan firman Allah SWT ketika menyangkal "sanggahan" malaikat atas penciptaan manusia sebagai khalifah di muka bumi. Dalam hal ini, Allah SWT membuktikan kemampuan manusia (Adam) dengan mengajarkannya nama-nama benda-benda yang ada di alam ini dan Adam pun mampu menerima apa yang diajarkan oleh Allah SWT, sedangkan malaikat tidak mampu melakukan apa yang dilakukan oleh Adam. 
Berkaitan dengan kebudayaan, E.B. Tylor (dalam Setiadi, 2006:27) menjelaskan bahwa budaya merupakan suatu keseluruhan kompleks yang meliputi pengetahuan, kepercayaan, kesenian, moral, keilmuan, hukum, adat istiadat, dan kemampuan yang lain serta kebiasaan yang didapat oleh manusia sebagai anggota masyarakat. Artinya, secara tidak langsung penjelaskan ini mengindikasaikan bahwa manusia adalah makhluk yang sangat dinamis yang mampu mempelajari seluruh kejadian alam semesta ini sehingga menjadikan manusia sebagai makhluk yang sempurna diantara makhluk-makhluk lainnya. Adapun menurut pandangan Islam, kebudayaan adalah manifestasi atau perwujudan segala aktifitas manusia sebagai upaya memenuhi kebutuhan hidupnya (Priyanto, 2016:90). Manusia dan kebudayaan merupakan kesatuan yang tidak terpisahkan, dan makhluk manusia merupakan pendukung kebudayaan. Sekalipun manusia akan mati, tetapi kebudayaan yang dimilikinya akan diwariskan untuk keturunannya, demikian seterusnya (Poerwanto, 2010:87).

\section{Unsur-unsur Pendidikan Islam dalam Perspektif Antropologi}

Noeng Muhadjir menjelaskan bahwa unsur-unsur pendidikan meliputi peserta didik, pendidik, tujuan, metode, serta konteks/lingkungan pendidikan.

\section{Pendidik dan Peserta didik dalam Pendidikan Islam}

Berkaitan dengan pendidik dan peserta didik, tentu tidak bisa dilepaskan dari pembicaran tentang manusia, lebih khusus lagi tentang fitrah manusia. Pendidik dan peserta didik merupakan dua unsur dalam 
pendidikan yang diperankan oleh manusia. Dalam hal ini keduanya merupakan unsur yang paling sering mengadakan interaksi baik secara langsung maupun tidak langsung. Pendidik dan peserta didik dalam hal ini selalu terlibat dalam aktivitas kebudayaan khususnya budaya pendidikan. Rasulullah SAW bersabda sebagaimana yang diriwayatkan oleh Abu Hurairah:

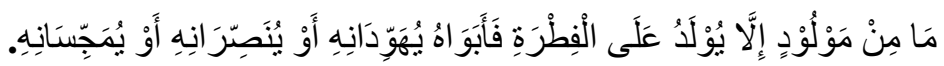
Tiada dari seorangpun yang dilahirkan kecuali ia dilahirkan dalam keadaan suci (fitrah), lalu kedua orang tuanya lah yang menjadikannya Yahudi, Nasrani, atau Majusi (al-Bukhārī, 1976:456).

Secara tidak langsung hadis di atas mengindikasikan bahwa setiap manusia yang baru dilahirkan memiliki beberapa potensi, termasuk diantaranya potensi untuk dididik. Dari potensi yang ada itu, akan sangat tergantung pada sosok yang mampu mengarahkan potensinya, apakah akan dibawa ke arah yang positif atau di bawa ke arah yang negatif. Dengan adanya ungkapan bahwa kedua orang tua yang akan menjadikannya Yahudi, Nasrani, atau Majusi adalah indikasi bahwa peran dari pendidik sangat menentukan perkembangan potensi yang dimiliki oleh peserta didik. Meskipun dalam hadis tersebut yang disebutkan adalah kedua orang tua (orang tua biologis), akan tetapi dalam kontekstualisasinya, tentu tidak hanya merujuk pada kedua orang tua secara biologis saja, melainkan merujuk pada siapa pun yang memiliki peran sebagai orang tua bagi setiap peserta didik baik secara formal, informal, maupun non formal.

Samsul Nizar (2002:42) sebagaimana dikutip oleh Mahmud menjelaskan bahwa pendidik adalah orang yang bertanggungjawab 
terhadap upaya perkembangan jasmani dan rohani peserta didik agar mencapai tingkat kedewasaan sehingga ia mampu menjalankan tugastugas kemanusiaan (baik sebagai khalīfah fil ard maupun ' $a b d$ ) sesuai dengan nilai-nilai ajaran Islam (Mahmud, 2012:154). Adapun peserta didik mernurut Undang-Undang Sisdiknas Pasal 1 ayat 4 adalah anggota masyarakat yang berusaha mengembangkan potensi diri melalui proses pembelajaran yang tersedia pada jalur, jenjang, dan jenis pendidikan tertentu (UU Sisdiknas:2). Dalam pendidikan Islam yang menjadi peserta didik bukan hanya anak-anak, melainkan juga orang dewasa yang masih berkembang, baik fisik maupun psikis. Hal itu sesuai denga prinsip bahwa pendidikan Islam berakhir setelah seseorang meninggal dunia (Umar, 2010:103).

Dalam pendidikan Islam, pendidik adalah orang yang bertanggung jawab terhadap prkembangan peserta didik dengan upaya mengembangkan seluruh potensi peserta didik, baik potensi afektif (rasa), kognitif (cipta), maupun psikomotorik (karsa) (Umar, 2010:83). Dengan demikian, peserta didik diharapkan menjadi sosok individu yang memiliki kemampuan rasa, cipta, dan karsa. Artinya, jika dipandang dari segi antropologis, seorang pendidik harus mampu membuat peserta didiknya menjadi sosok yang berbudaya dengan cara mengembangkan aspek rasa, cipta, dan karsa. Selo Soemardjan dan Soelaeman Soemardi menjelaskan bahwa kebudayaan adalah semua hasil karya, rasa, dan cipta manusia (Setiadi, 2006:28). 


\section{Tujuan Pendidikan Islam}

Tujuan secara bahasa dimaknai sebagai arah, haluan (jurusan) yang dituju, maksud, dan tuntutan (yang dituntut) (Tim Penyusun Kamus Pusat Bahasa, 2008:1739). Adapun dalam konteks pendidikan secara umum, tujuan pendidikan sebagaimana terdapat dalam Undang-Undang Sisdiknas adalah berkembangnya potensi peserta didik agar menjadi manusia yang beriman dan bertakwa kepada Tuhan Yang Maha Esa, berakhlak mulia, sehat, berilmu, cakap, kreatif, mandiri, dan menjadi warga negara yang demokratis serta bertanggungjawab (UU Sisdiknas:4).

Sementara itu, secara lebih khusus tujuan pendidikan Islam adalah untuk membentuk akhlak mulia, persiapan kehidupan dunia akhirat, persiapan untuk mencari rizki, menumbuhkan semangat ilmiah, dan menyiapkan profesionalisme subjek didik (Roqib, 2016:40). Dari semua tujuan yang telah disebutkan tersebut, menunjukkan bahwa setiap output pendidikan Islam harus memiliki kemampuan secara komprehensif baik hubungannya dengan diri pribadi maupun hubungannya dengan orang lain.

Berbicara tujuan pendidikan, tentu tidak dapat lepas dari tujuan hidup manusia itu sendiri mengingat pendidikan merupakan salah satu aspek penentu arah kehidupan manusia. Allah SWT berfirman:

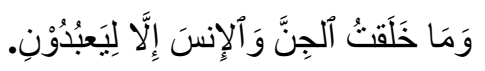

Dan aku tidak menciptakan jin dan manusia melainkan supaya mereka mengabdi kepada-Ku (Q.S. al-Zariyat).

Ayat ini menjelaskan bahwa tujuan Allah SWT menciptakan manusia di muka bumi ini tidak lain adalah untuk beribadah kepada Allah SWT. Dengan demikian, maka seluruh aktifitas manusia termasuk 
di dalamnya adalah aktifitas pendidikan hendaknya ditujukan untuk beribadah kepada Allah SWT, artinya dalam melakukan aktifitas pendidikannya hendaknya setiap manusia memiliki tujuan dalam hatinya untuk mengharap ridla dari Allah SWT. Ibadah dalam hal ini tentunya tidak hanya ibadah yang berbentuk ritual semata melainkan juga ibadah yang bersifat ibadah sosial, yakni ibadah yang tidak hanya untuk diri sendiri tetapi juga ibadah yang berkaitan dengan interaksinya dengan orang lain, atau bahkan makhluk lain. Ibadah jenis kedua inilah yang pada akhirnya akan mampu membentuk sebuah tatanan kebudayaan dalam masyarakat, yakni kebudayaan yang berlandaskan ajaran Islam.

Dalam pandangan ilmu antropologi, setiap manusia bukan hanya makhluk yang berkebudayaan, melainkan juga mempunyai kelebihan luar biasa dalam menciptakannya dibandingkan dengan makhluk lain (Mahmud, 2012:154). Dalam artian setiap individu manusia akan menjadi faktor penentu lahirnya sebuah kebudayaan. Sehingga jika menusia yang ada merupakan manusia yang terdidik, maka kemungkinan besar kebudayaan yang lahir juga kebudayaan yang bernuansa pendidikan.

Untuk melahirkan individu yang berpendidikan, tentunya harus melalui suatu proses yang disebut pendidikan. Setelah manusia menempuh suatu proses pendidikan, maka diharapkan manusia tersebut mencapai tujuan-tujuan yang telah dirumuskan oleh pendidikan dalam hal ini tentunya tujuan yang bernuansa Islam. Setelah manusia tadi mencapai tujuan pendidikan yang telah dirumuskan, hendaknya 
diaplikasikan dalam kehidupan nyata bersama individu yang lain yang akhirnya akan melahirkan kebudayaan.

\section{Metode Pendidikan Islam}

Metode menurut Kamus Bahasa Indonesia memiliki arti cara yang teratur dan terpikir baik-baik atau berdasarkan pemikiran yang matang untuk mencapai suatu maksud (dalam ilmu pengetahuan dan sebagainya), cara kerja yang bersistem untuk memudahkan pelaksanaan suatu kegiatan guna mencapai tujuan atau maksud yang ditentukan (Tim Penyusun Kamus Pusat Bahasa, 2008:1022). Adapun dalam konteks pendidikan Islam, metode diartikan sebagai cara-cara yang digunakan dalam mengembangkan potensi peserta didik untuk mencapai tujuan pendidikan Islam (Umar, 2010:181). Cara tentunya bukanlah tujuan inti dari sebuah aktifitas pendidikan, namun demikian cara menjadi faktor penentu kesuksesan sebuah aktifitas pendidikan.

Dalam pendidikan Islam, sebagaimana dikemukakan oleh Abdurrahman al-Naḥlawi (2010:167-233), metode pendidikan Islam adalah sebagai berikut: 1) pendidikan dengan al-qașaș al-Qur'ānī dan alnabawī; 2) pendidikan dengan perumpamaan; 3) pendidikan dengan keteladanan; 4) pendidikan dengan latihan dan pengamalan; 5) pendidikan dengan 'ibrah dan mau'izah; 6) pendidikan dengan targīb dan tarhīb. Akan tetapi dalam tulisan ini, penulis tidak akan membahas satu persatu metode yang telah disebutkan di atas. Hal ini karena dalam tulisan ini, penulis ingin menekankan pada bagaiamana pandangan antropologi terhadap pendidikan Islam yang artimya termasuk di 
dalamnya adalah bagaimana pandangan antropologi terhadap metode pendidikan Islam.

Metode secara sederhana dimaknai sebagai cara. Sehingga yang menjadi pertanyaan adalah bagaimana pandangan ilmu antropologi terhadapa cara-cara pentransferan ilmu dari pendidik ke peserta didik? Untuk bisa menjawab pertanyaan tersebut tentunya perlu untuk melihat kembali konsep dasar antropologi.

Jika antropologi dipandang sebagai ilmu tentang manusia, maka barangkali akan memaknai metode sebagai sebuah cara manusia dalam kapasitasnya sebagai makhluk yang berbudaya dalam rangka menyampaikan ilmu pengetahuan dalam sebuah aktifitas pendidikan. Sehingga, dengan demikian metode pendidikan dalam perspektif antropologi akan sangat tergantung pada budaya setempat dimana manusia itu berada. Manusia atau sekelompok manusia dalam kebudayaan Jawa yang kuat tentu dalam memberikan pengajaran atau pendidikan kepada anak didiknya tidak akan lepas dari pengaruh kebudayaan Jawa. Bahkan Nabi Muhammad SAW pun telah mencontohkan dalam hadisnya perihal cara menyampaikan sesuatu materi harus melihat pada budaya setempat.

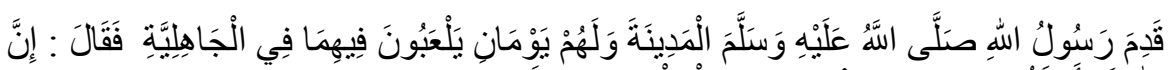

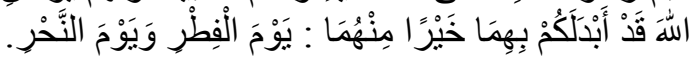
Diriwayatkan dari Anas, ia berkata: "Ketika Rasulullah saw tiba di Madinah, penduduk telah memiliki dua hari (Nairuz dan Mahrajan) yang dijadikan sebagai hari bersenang-senang mereka pada zaman Jahiliyah. Kemudian Rasulullah saw bersabda: 'Sesungguhnya Allah SWT telah menggantikan kedua hari itu bagi kaliah dengan yang lebih baik, yaitu hari raya 'Idul Fitri dan hari raya Nahr','(Ibnu Hambal, 1998:850). 
Dalam hadis tersebut dijelaskan tentang latar belakangnya bahwa di Madinah, sebelum Rasulullah SAW berhijrah, telah ada dua hari raya yang digunakan untuk bersenang-senang pada zaman Jahiliyah yaitu hari Nairuz dan Mahrajan. Akan tetapi setelah Rasulullah SAW datang ke Madinah, beliau tidak serta merta membuang budaya tersebut, hanya saja beliau tentunya atas wahyu dari Allah SWT menggantinya dengan hari raya bagi umat Islam yaitu Idul Fitri dan Idul Adha. Dalam hal ini Rasulullah SAW sangat menghargai budaya setempat yang sudah ada dan tidak menghilangkannya, namun hanya mengganti tradisi Jahiliyah dengan tradisi Islam.

Jika dianalogikan dalam dunia pendidikan, maka dapat dipahami bahwa pendidikan Islam juga hendaknya tidak serta merta mengganti budaya yang sudah ada di lingkungan setempat, akan tetapi justru dijadikan sebagai jalan atau metode pendidikan dan tentunya disesuaikan dengan ajaran Islam. Hal ini juga senada dengan salah satu pemikiran Barat modern yang disebuat dengan pandangan eksternalis ilmiah yang berpandangan bahwa ide-ide ilmu pengetahuan dibentuk oleh pengaruh budaya eksternal. Mereka menegaskan bahwa ilmu pengetahuan tidak muncul secara obyektif akan tetapi muncul secara subyektif dan relatif (Mahmud, 2012:147).

\section{Konteks/Lingkungan Pendidikan Islam}

Peristiwa pengasuhan Nabi Muhammad SAW oleh Halimatus Sa'diah selama 2 tahun di perkampungan Bani Sa'd, sebagaimana juga yang umum dilakukan masyarakat Arab ketika itu terhadap bayi-bayi mereka 
merupakan salah satu upaya yang bertujuan untuk menguatkan fisik dan mental anak-anak mereka, sehingga kelak anak-anak tersebut tumbuh besar menjadi pribadi-pribadi yang memiliki kekuatan fisik dan mental (Amin, 2013:109). Meskipun sebagian ulama berpendapat bahwa kesempurnaan Nabi Muhammad SAW bukan berasal dari lingkungannya melainkan dari dalam dirinya sendiri atas bimbingan dari Tuhannya (Amin, 2013:110), namun jika melihat pada sifat basyariyah Nabi Muhammad SAW, tentunya lingkungan akan menjadi hal yang sangat berpengaruh bagi keberlangsungan hidupnya, khususnya untuk mengembangkan potensi yang ada dalam dirinya. Maka dari itu, lingkungan pendidikan akan sangat mempengaruhi tingkat keberhasilan sebuah aktifitas pendidikan, termasuk pendidikan Islam.

Lingkungan atau konteks, menurut Noeng Muhadjir dapat berperan positif dapat juga negatif. Upaya pendidikan perlu secara aktif menyisihkan yang negatif atau mengubahnya menjadi positif, atau mengoptimalkan peran yang positif dan mengeliminir atau meminimalkan peran yang negatif (Muhadjir, 2003:4). Dengan demikian lingkungan hendaknya diciptakan agar mendukung aktifitas pendidikan. Semisal sebuah sekolah atau lembaga pendidikan lainnya harus mampu menciptakan lingkungan yang kondusif untuk belajar, sehingga peserta didik akan merasa nyaman mengikuti pelajaran di dalamnya. Dalam pemahaman lain, lingkungan hendaknya bisa dijadikan sebagai salah satu pertimbangan dalam rangka menyelenggarakan suatu akvifitas pendidikan. Lingkungan di sini tentunya bukan hanya lingkungan sekolah yang notabene merupakan lingkungan pendidikan, akan tetapi 
lingkungan-lingkungan lain seperti keluarga dan masyarakat juga harus bisa mendukung keberhasilan pendidikan setiap individu. Kondisi lingkungan keluarga dan masyarakat akan sangat berpengaruh terhadap perilaku setiap individu. Terlabih lagi keluarga, peran orang tua merupakan kunci keberhasilan pendidikan bagi anak-anaknya.

Berkaitan dengan peran lingkungan dalam pendidikan Islam, Nabi Muhammad saw bersabda sebagai berikut.

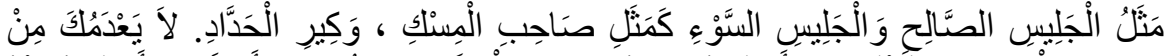

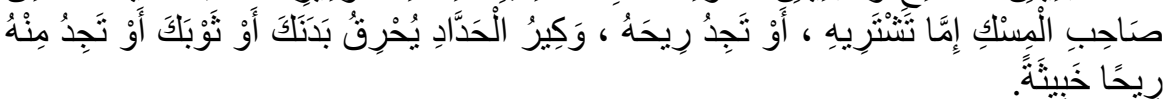

Perumpamaan teman bergaul yang baik dan teman bergaul yang buruk, adalah seperti orang yang membawa minyak wangi (pedagang minyak wangi) dan tukang besi. Pembawa (pedagang) minyak wangi itu, (bila selalu bersamanya) bolehjadi engkau akan membelinya atau engkau akanmendapatkan bau (wangi) dari minyak itu, sedangkan tukan besi, (bila engaku selalu bersamanya), bisa jadi bajumu terbakar oleh percikan apinya, atau engkau akan terkena asap yang tidak sedap baunya. (al-Bukhārī, 1976:741).

Dari hadis tersebut dapat dipahami bahwa teman bergaul atau lebih luas lagi lingkungan akan sangat mempengatuhi pribadi seseorang. Teman (lingkungan) yang baik akan memberikan pengaruh baik pada seseorang, sedangkan teman (lingkungan) yang buruk akan membawa pengaruh buruk bagi seseorang.

\section{Simpulan}

Islam dan antropologi memiliki pandangan yang sama terkait dengan pendidikan Islam. Kesamaan tersebut diantaranya terlihat pada kesamaan pandangan tentang konsep manusia. Manusia sebagai makhluk yang memiliki potensi atau fitrah sama-sama diakui oleh antropologi dan 
Islam. Begitu pula dalam aktifitas pendidikan, antara Islam dan antropologi pun memiliki beberapa kesamaan yang tentunya kesamaan tersebut dari segi substansinya.

Unsur-unsur pendidikan terdiri dari pendidik, peserta didik, tujuan pendidikan, metode pendidikan, serta konteks/lingkungan. Pendidikan hendaknya bisa disesuaikan dengan kebudayaan yang ada di sekitar. Hal ini karena selain antropologi menghendaki yang demikian, ternyata Islam juga sangat mengapresiasi mereka yang menghargai budayanya, tentunya budaya-budaya yang tidak bertentangan dengan prinsip-prinsip ajaran Islam. Pada akhirnya, antropologi memandang pendidikan Islam sebagai suatu perwujudan manusia dalam melestarikan budaya pendidikannya dengan dijiwai spirit Islam.

\section{Daftar Pustaka}

Undang-Undang Republik Indonesia Nomor 20 Tahun 2003 tentang Sistem Pendidikan Nasional.

Agus, B. (2006). Agama dalam Kehidupan Manusia Pengantar Antropologi Agama. Jakarta: Rajawali Press.

Amin, M. R. (2013). Rasulullah Sang Pendidik: Menyingkap Rahasiarahasia Pendidikan Karakter dari Sirah Nabi Muhammad Saw. Jakarta: AMP Press.

Azra, A. (2012). Pendidikan Islam: Tradisi dan Modernisasi di Tengah Tantangan Milenium III. Jakarta: Kencana.

al-Bukhārī, A. A. M. (1976). Beirut: Dāru ibnu Kas̄īr.

Geller, D. N. (2012). "Pendekatan Antropologis" dalam Aneka Pendekatan Studi Islam, ed. Peter Connolly. Yogyakarta: LKiS.

Hambal, A. (1998). Musnad al-Imām al-Hāafiz Ab̄̄ 'Ābdillāh Aḥmad bin Hambal. Riyaḍ: Bait al-Afkār ad-Dauliyyah li an-Nasyr wa atTauzī'. 
Harsojo. (1982). Pengantar Antropologi. t.k.: Binacipta.

Koentjaraningrat. (1990). Pengantar Ilmu Antropologi cet VIII. Jakarta: Rhineka Cipta.

Mahmud. (2012). Antropologi Pendidikan. Bandung: Pustaka Setia.

Makbuloh, D. (2011). Pendidikan Agama Islam: Arah Baru Pengembangan Ilmu dan Kepribadian di Perguruan Tinggi. Jakarta: Rajawali Pers.

Moloeng, L. J. (2014). Metodologi Penelitian Kualitatif. Bandung: Remaja Rosdakarya.

Muhadjir, N. (2003). Ilmu Pendidikan dan Perubahan Sosial: Teori Pendidikan Pelaku Sosial Kreatif. Yogyakarta: Rake Sarasin.

an-Naḥlāwī, 'A. (2010). Ușūl at-Tarbiyyah al-Islāmiyyah wa Asālībuhā fi al-Baiti wa al-Madrasati wa al-Mujtama’i. Damaskus: Dār alFikr.

Poerwanto, H. (2010). Kebudayaan dan Lingkungan dalam Perspektif Antropologi. Yogyakarta: Pustaka Pelajar.

Priyanto, D. (2016). Relevansi Konsepsi Pendidikan Ki Hadjar Dewantara Terhadap Pendidikan Islam, dalam Jurnal Educreative, Vol. 1, No. 2.

Rofiq, Z. (2014). Manusia dalam Pendidikan Islam, dalam Jurnal AtTajdid, Vol. 3, No. 1.

Roqib, M. (2016). Filsafat Pendidikan Profetik: Pendidikan Islam Integratif dalam Perspektif Kenabian Muhammad saw. Purwokerto: Pesma An-Najah Press.

Roqib, M. (2009). Ilmu Pendidikan Islam: Pengembangan Pendidikan Integratif di Sekolah, Keluarga, dan Masyarakat. Yogyakarta: LKiS.

Ruslan, R. (2004). Metode Penelitian Public Relations dan Komunikasi. Jakarta: Raja Grafindo Persada.

Setiadi, E. M., dkk. (2006). Ilmu Sosial dan Budaya Dasar. Jakarta: Kencana.

Shomad, A. (2004). Selayang Pandang tentang Antropologi Pendidikan Islam, dalam Jurnal Pendidikan Agama Islam, Vol. 1, No. 1. 
Sutrisno. (2006). Fazlur Rahman: Kajian tehadap Metode, Epistemologi dan Sistem Pendidikan. Yogyakarta: Pustaka Pelajar.

Syukur, F. (2012). Sejarah Pendidikan Islam. Semarang: Pustaka Rizki Putra.

Tafsir, A. (2014). Filsafat Pendidikan Islami. Bandung: Remaja Rosdakarya.

Tanzeh, A. (2011). Metodologi Penelitian Praktis. Yogyakarta: Teras.

Tim Penyusun Kamus Pusat Bahasa. (2008). Kamus Bahasa Indonesia. Jakarta: Pusat Bahasa.

Umar, B. (2010). Ilmu Pendidikan Islam. Jakarta: Amzah. 
Mudarrisa, Jurnal Kajian Pendidikan Islam, Vol. 8, No. 2, Desember 2016: 201-228 